\title{
ESI-MS Detection of Very Weak $\pi$-Stacking Interactions in the Mixed-Ligand Sandwich Complexes Formed by Substituted Benzo-Crown Ethers and Metal Cations
}

\author{
Rafał Frański and Błażej Gierczyk \\ Faculty of Chemistry, Adam Mickiewicz University, Poznań, Poland
}

The stability of the mixed-ligand complex formed by amino-benzo-15-crown-5 and nitro-benzo15-crown-5, with a metal cation, $\left[\mathrm{NH}_{2} \mathrm{~B} 15 \mathrm{C} 5+\mathrm{NO}_{2} \mathrm{~B} 15 \mathrm{C} 5+\mathrm{K}\right]^{+}$, was found to be enhanced by $\pi$-stacking interactions. This conclusion was deduced by comparison of the abundance of the mixed-ligand complex with the abundances of homo-ligand complexes $\left(\left[\left(\mathrm{NH}_{2} \mathrm{~B} 15 \mathrm{C} 5\right)_{2}+\right.\right.$ $\mathrm{K}]^{+},\left[\left(\mathrm{NO}_{2} \mathrm{~B} 15 \mathrm{C} 5\right)_{2}+\mathrm{K}^{+}\right)$, as well as with those of $1: 1$ complexes $\left(\left[\mathrm{NH}_{2} \mathrm{~B} 15 \mathrm{C} 5+\mathrm{K}\right]^{+}\right.$, $\left.\left[\mathrm{NO}_{2} \mathrm{~B} 15 \mathrm{C} 5+\mathrm{K}\right]^{+}\right)$. Some solvents and some metal cations with large radii were also found to prevent the existence of $\pi$-stacking interactions. (J Am Soc Mass Spectrom 2010, 21, 545-549) (c) 2010 American Society for Mass Spectrometry

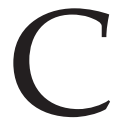

rown ethers are popular hosts, and their inclusion complexes have found a vast number of practical applications [1]. Most studies devoted to crown ether complexes with metal cations have focused on complexes with 1:1 stoichiometry. However, complexes of 2:1 stoichiometry ("sandwich" type complexes) are also known. Complexes of this type are formed when the radius of the metal cation is greater than the size of the crown ether cavity [2]. A number of sandwich type complexes have been successfully studied in detail in the gas phase [3-5]; some of them contained ammonium cation instead of a metal cation [6]. An interesting paper devoted to the sandwich type complexes formed by crown ethers is that published by Sherman et al. [7], who demonstrated that the stability of mixed-ligand sandwich type complexes can be enhanced by $\pi$-stacking interactions between two aromatic rings, one of which is enriched in electrons, while the other is poor in electrons; $\pi$-stacking interactions have been also observed for some complexes of crown ethers with substituted ammonium cation [8, 9]. Encouraged by this paper [7], and taking into account the importance of $\pi$-stacking interactions [10-12], we have examined whether such interactions exist in the sandwich complexes formed by amino-benzo-15-crown-5 $\left(\mathrm{NH}_{2} \mathrm{~B} 15 \mathrm{C} 5\right)$ and nitro-benzo-15-crown-5 ( $\left.\mathrm{NO}_{2} \mathrm{~B} 15 \mathrm{C} 5\right)$. Due to resonance effects, the aromatic ring of the first compound is rich in electrons while the aromatic ring in the latter compound is poor in electrons. For comparison benzo-15-crown-5 (B15C5) has been also included in the study (Scheme 1).

Address reprint requests to Dr. R. Frański, Faculty of Chemistry, Adam Mickiewicz University, Grunwaldzka 6, 60-780 Poznań, Poland. E-mail: franski@amu.edu.pl

\section{Experimental}

The ESI mass spectra were obtained on a Waters/ Micromass (Manchester, UK) ZQ2000 mass spectrometer (single quadrupole type instrument, Z-spray, software MassLynx ver. 3.5). The sample solutions were prepared in methanol (or other solvent), at crown ether concentrations of $0.7 \times 10^{-5} \mathrm{~mol} / \mathrm{dm}^{3}$ (or similar as indicated). At this low concentration, the 2:1 complexes were characterized by low abundances in comparison to those of the 1:1 complexes; therefore the $m / z$ range of the 2:1 complexes is magnified 10 times in Figure 1. Sherman et al. [7] used a concentration of $5 \times 10^{-5}$ $\mathrm{mol} / \mathrm{dm}^{3}$; however, we employed a lower concentration to minimize contamination of the instrument.

Signals of $[\mathrm{M}+\mathrm{Na}]^{+},[\mathrm{M}+\mathrm{K}]^{+}$, and $\left[\mathrm{M}_{2}+\mathrm{Na}\right]^{+}$ were clearly seen $(\mathrm{M}=$ crown ether molecule) without adding inorganic salts (Figure 1). Thus, the concentrations of $\mathrm{Na}^{+}$and $\mathrm{K}^{+}$were not known. ESI mass spectra were also obtained with $\mathrm{KClO}_{4}, \mathrm{KCl}$, or $\mathrm{NaCl}$ added. To observe complexes with rubidium or cesium, $\mathrm{RbClO}_{4}$ or $\mathrm{CsClO}_{4}$ were added to the solutions analyzed (concentration about $\left.0.4 \times 10^{-5} \mathrm{~mol} / \mathrm{dm}^{3}\right)$. The experiments were repeated at least three times. In the repeated measurements, the mass spectrum was recorded for both the previously used solution and for the newly prepared solution.

The sample solutions were infused into the ESI source using a Harvard pump at a flow rate of 80 $\mu \mathrm{L} / \mathrm{min}$. The ESI source potentials were capillary $3 \mathrm{kV}$, lens $0.5 \mathrm{kV}$, extractor $4 \mathrm{~V}$, and cone voltage $5 \mathrm{~V}$. This last parameter had the most profound effect on the mass spectra obtained. Increase in this voltage leads to the so-called "in-source" fragmentation/dissociation, but a too low cone voltage may cause a drop in sensitivity. A 


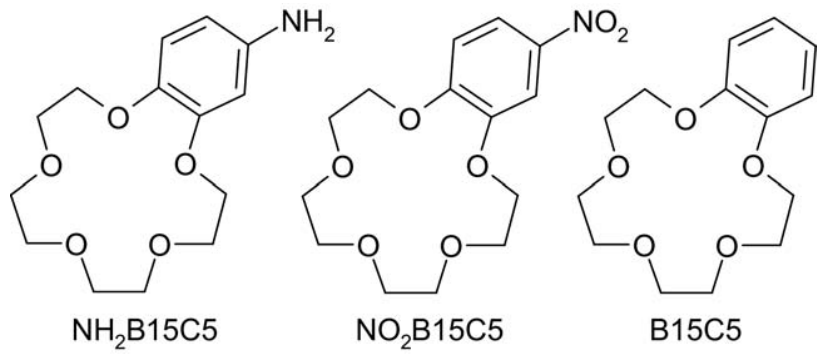

Scheme 1. Crown ethers studied in this work.

low cone voltage of $5 \mathrm{~V}$ minimizes the fragmentation/ dissociation process. The source temperature was $120{ }^{\circ} \mathrm{C}$ and the desolvation temperature was $300^{\circ} \mathrm{C}$.
Nitrogen was used as the nebulizing and desolvating gas at flow-rates of 100 and $300 \mathrm{l} \mathrm{h}^{-1}$, respectively.

B15C5 and $\mathrm{NH}_{2} \mathrm{~B} 15 \mathrm{C} 5$ were obtained from SigmaAldrich and used without further purification. $\mathrm{NO}_{2} \mathrm{~B} 15 \mathrm{C} 5$ was synthesized by nitration of B15C5 with a nitric acid (60\%) and sulfuric acid (98\%) mixture (1:3, $\mathrm{vol} / \mathrm{vol})$ at $10{ }^{\circ} \mathrm{C}$. After dilution with water, the products were collected by filtration and purified by crystallization from ethanol; the yield was about $70 \%$.

\section{Results and Discussion}

Sherman et al. [7] took into consideration the following reaction:
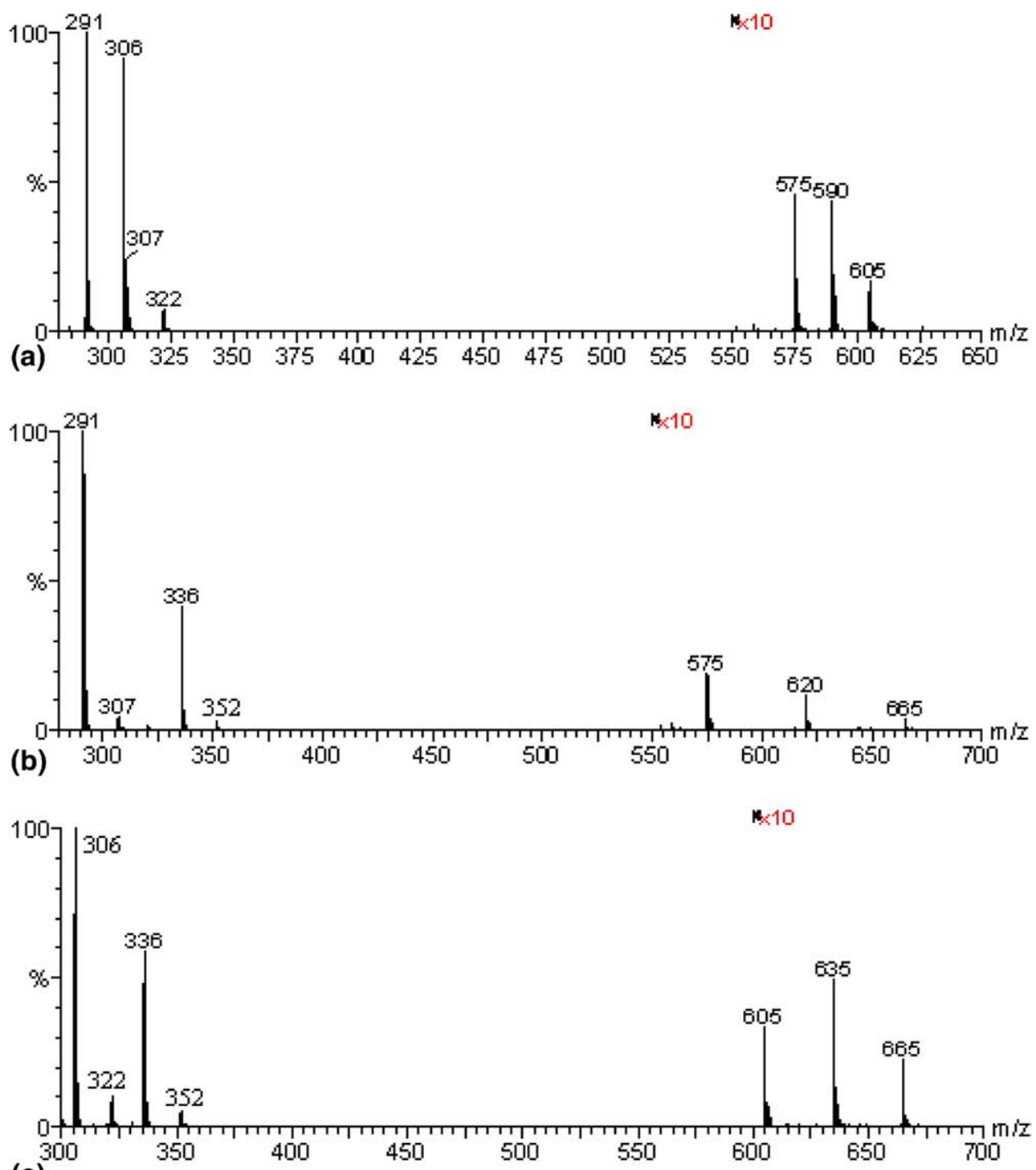

(c)

Figure 1. ESI mass spectra of methanol solutions containing (a) $\mathrm{B} 15 \mathrm{C} 5$ and $\mathrm{NH}_{2} \mathrm{~B} 15 \mathrm{C} 5$, (b) $\mathrm{B} 15 \mathrm{C} 5$ and $\mathrm{NO}_{2} \mathrm{~B} 15 \mathrm{C} 5$, (c) $\mathrm{NH}_{2} \mathrm{~B} 15 \mathrm{C} 5$ and $\mathrm{NO}_{2} \mathrm{~B} 15 \mathrm{C} 5$. [B15C5 $\left.+\mathrm{Na}\right]^{+} \mathrm{m} / \mathrm{z} 291,[\mathrm{~B} 15 \mathrm{C} 5+\mathrm{K}]^{+} \mathrm{m} / \mathrm{z}$ 307-this peak overlaps with isotope peak of $\left[\mathrm{NH}_{2} \mathrm{~B} 15 \mathrm{C} 5+\mathrm{Na}\right]^{+} \mathrm{m} / \mathrm{z} 306,\left[\mathrm{NH}_{2} \mathrm{~B} 15 \mathrm{C} 5+\mathrm{K}\right]^{+} \mathrm{m} / \mathrm{z} 322$, $\left[\mathrm{NO}_{2} \mathrm{~B} 15 \mathrm{C} 5+\mathrm{Na}\right]^{+} m / z 336,\left[\mathrm{NO}_{2} \mathrm{~B} 15 \mathrm{C} 5+\mathrm{K}\right]^{+} m / z 352,\left[(\mathrm{~B} 15 \mathrm{C} 5)_{2}+\mathrm{K}\right]^{+} m / z 575,\left[\left(\mathrm{NH}_{2} \mathrm{~B} 15 \mathrm{C} 5\right)_{2}+\mathrm{K}\right]^{+}$ $m / z$ 605, $\left[\left(\mathrm{NO}_{2} \mathrm{~B} 15 \mathrm{C} 5\right)_{2}+\mathrm{K}\right]^{+} m / z 665,\left[\mathrm{NH}_{2} \mathrm{~B} 15 \mathrm{C} 5+\mathrm{B} 15 \mathrm{C} 5+\mathrm{K}\right]^{+} m / z 590,\left[\mathrm{NH}_{2} \mathrm{~B} 15 \mathrm{C} 5+\mathrm{NO}_{2} \mathrm{~B} 15 \mathrm{C} 5+\right.$ $\mathrm{K}]^{+} m / z$ 635, $\left[\mathrm{B} 15 \mathrm{C} 5+\mathrm{NO}_{2} \mathrm{~B} 15 \mathrm{C} 5+\mathrm{K}\right]^{+} m / z 620$. 


$$
\left[\mathrm{A}_{2} \mathrm{M}\right]^{+}+\left[\mathrm{B}_{2} \mathrm{M}\right]^{+} \Leftrightarrow 2[\mathrm{ABM}]^{+}
$$

where $\mathrm{A}$ and $\mathrm{B}$ are two different crown ethers and $\mathrm{M}$ is a metal cation. The equilibrium constant of this reaction is:

$$
K=\frac{\left([A B M]^{+}\right)^{2}}{\left[A_{2} M\right]^{+}\left[B_{2} M\right]^{+}}
$$

As clearly justified by the authors [7], the concentrations of the homo-ligand complexes $\left(\left[\mathrm{A}_{2} \mathrm{M}\right]^{+}\right.$and $\left[\mathrm{B}_{2} \mathrm{M}\right]^{+}$) as well as the concentration of the mixedligand complex $\left([\mathrm{ABM}]^{+}\right)$can be replaced by respective peak intensities in the ESI mass spectra obtained. Further, in the same paper the Gibbs free-energy was calculated as $\Delta \mathrm{G}=-\mathrm{RT} \operatorname{lnK}$, and it was concluded that "large positive $\Delta G$ values signify that the homo-ligand complexes are favored, near-zero values mean that the homo-ligand and mixed-ligand complexes are equally favored, and large negative values reflect a strong preference for formation of mixed-ligand sandwich complexes."

In our opinion, in the situation where the homoligand and mixed-ligand complexes are equally favored, the concentration/peak intensity ratio of $\left[\mathrm{A}_{2} \mathrm{M}\right]^{+}:[\mathrm{ABM}]^{+}$: $\left[\mathrm{B}_{2} \mathrm{M}\right]^{+}$must be $1: 2: 1$, assuming that $\mathrm{A}$ and $\mathrm{B}$ have equal affinity toward $M$. When the affinity of $A$ toward $M$ is two times higher than that of $B$ toward $M$, the ratio should be 4:4:1, and when the affinity of $A$ toward $M$ is three times higher than that of $B$ toward $M$, the ratio should be 9:6:1 (see Supplemental Information, which can be found in the electronic version of this article, for the calculation). In all cases, $\mathrm{K}=4$ and the calculated Gibbs free-energy is $\Delta \mathrm{G}=-8.31 \times 298 \times \ln 4=-3433 \mathrm{~J} / \mathrm{mol}$.

Figure 1 shows the ESI mass spectra of methanol solutions, each of which contains two of the three crown ethers studied (similar spectra were obtained when $\mathrm{K}^{+}$ion was added to the analyzed solution; see Supplemental Information). The diameter of the 15 -crown- 5 cavity is $170-220 \mathrm{pm}$ [13] and the diameters of the molecules of the benzo derivatives studied in this work can be considered as nearly the same (or slightly smaller [14]. The diameters of $\mathrm{Na}^{+}$and $\mathrm{K}^{+}$cations are $196 \mathrm{pm}$ and $266 \mathrm{pm}$, respectively [15]. Therefore, the latter cation is able to form sandwich type complexes (complexes of stoichiometry 2:1) with the crown ethers studied.

As follows from the results in Figure 1, B15C5 is much more prone to form complexes with alkali metal cations than $\mathrm{NO}_{2} \mathrm{~B} 15 \mathrm{C} 5$, and only slightly more prone than $\mathrm{NH}_{2} \mathrm{~B} 15 \mathrm{C} 5$. This can be concluded on the grounds of peak intensities of both 1:1 and 2:1 complexes (Figure $1 \mathrm{a}$ and $\mathrm{b}$ ). Therefore, it can be expected that $\mathrm{NH}_{2} \mathrm{~B} 15 \mathrm{C} 5$ is also much more prone to form complexes with alkali metal cations than $\mathrm{NO}_{2} \mathrm{~B} 15 \mathrm{C} 5$. As shown in Figure 1c, this is true only for 1:1 complexes. Signal intensities of 2:1 complexes decrease in the order $\left[\mathrm{NH}_{2} \mathrm{~B} 15 \mathrm{C} 5+\mathrm{NO}_{2} \mathrm{~B} 15 \mathrm{C} 5+\right.$ $\mathrm{K}]^{+}>\left[\left(\mathrm{NH}_{2} \mathrm{~B} 15 \mathrm{C} 5\right)_{2}+\mathrm{K}\right]^{+}>\left[\left(\mathrm{NO}_{2} \mathrm{~B} 15 \mathrm{C} 5\right)_{2}+\mathrm{K}^{+}\right.$. The peak intensity ratio is close to $1: 2: 1\left(\left[\mathrm{~A}_{2} \mathrm{M}\right]^{+}:[\mathrm{ABM}]^{+}:\left[\mathrm{B}_{2} \mathrm{M}\right]^{+}\right.$, the situation when the homo-ligand and mixed-ligand complexes are equally favored and $\mathrm{A}$ and $\mathrm{B}$ have equal affinity toward $\mathrm{M}$ ). Because the crown ethers $\mathrm{NH}_{2} \mathrm{~B} 15 \mathrm{C} 5$ and $\mathrm{NO}_{2} \mathrm{~B} 15 \mathrm{C} 5$ definitely do not have the same affinity toward alkali metal cations, it is reasonable to conclude that the existence of $\pi$-stacking interactions in $\left[\mathrm{NH}_{2} \mathrm{~B} 15 \mathrm{C} 5+\mathrm{NO}_{2} \mathrm{~B} 15 \mathrm{C} 5+\mathrm{K}\right]^{+}$compensate for the lower complexing ability of $\mathrm{NO}_{2} \mathrm{~B} 15 \mathrm{C} 5$. It must be stressed that the ESI mass spectrum of a methanol solution containing $\mathrm{NH}_{2} \mathrm{~B} 15 \mathrm{C} 5$ and $\mathrm{NO}_{2} \mathrm{~B} 15 \mathrm{C} 5$ is the only one in which the mixed-ligand complex is more abundant than the homo-ligand complexes (Figure 1).

Different peak intensities in the ESI mass spectra can be a result of different ionization efficiencies of the ions analyzed. For example, hydrophobic effects can play a role. However, it was demonstrated that for alkali cation complexes, this effect is important for complexes of low stabilities [16]. Complexes of crown ethers with alkali metal ions can be regarded as rather stable ones, at least those of 1:1 stoichiometry. It is also expected that because the interactions of the $\mathrm{NH}_{2}$ group with methanol involve hydrogen bond formation in solution, the ionization efficiency (desolvation) of the $\mathrm{NH}_{2} \mathrm{~B} 15 \mathrm{C} 5$ complexes will be lowered. This was observed for copper complexes [17], which are less stable than alkali metal complexes. As shown in Figure 1, $\mathrm{NH}_{2}-\mathrm{B} 15 \mathrm{C} 5$ complexes are abundant.

The results of ESI-MS analysis of the host-guest complexes (including those involving macrocycles) correlate well with the measurements of the equilibriums in solution $[7,18]$. It has been clearly demonstrated by Brodbelt and coworkers that the host-guest complexes, which have similar conformations and structural features, such as a simple crown ether binding to two different alkali metal ions, have similar electrospray ionization efficiencies [19].

To verify whether the relative peak intensities in the ESI mass spectra (for the complexes of the crown ethers used in this work) reflect the relative concentrations in solution, the ESI mass spectra were taken at high excess of alkali metal cations, $\mathrm{Na}^{+}$and $\mathrm{K}^{+}$(Figure 2). Under such conditions, almost all of the crown ether molecules $\left(\mathrm{NH}_{2} \mathrm{~B} 15 \mathrm{C} 5\right.$ and $\left.\mathrm{NO}_{2} \mathrm{~B} 15 \mathrm{C} 5\right)$ are in the form of complexes with the alkali metal cation. If the concentrations of $\mathrm{NH}_{2} \mathrm{~B} 15 \mathrm{C} 5$ and $\mathrm{NO}_{2} \mathrm{~B} 15 \mathrm{C} 5$ are the same, the resulting concentrations of the complexes (e.g., $\left[\mathrm{NH}_{2} \mathrm{~B} 15 \mathrm{C} 5+\right.$ $\mathrm{Na}]^{+}$and $\left[\mathrm{NO}_{2} \mathrm{~B} 15 \mathrm{C} 5+\mathrm{Na}\right]^{+}$) will also be the same or very similar. If the ESI responses (spray efficiencies) of the complexes are similar, the respective peak intensities, obviously, will be also similar.

As demonstrated in Figure 2, the respective peak intensities are very similar, especially for the ions $\left[\mathrm{NH}_{2} \mathrm{~B} 15 \mathrm{C} 5+\mathrm{Na}\right]^{+}$and $\left[\mathrm{NO}_{2} \mathrm{~B} 15 \mathrm{C} 5+\mathrm{Na}\right]^{+}$; the latter has $95 \%$ relative intensity of the former, indicating that complexes of the crown ethers have similar ESI responses. Ions $\left[\mathrm{NH}_{2} \mathrm{~B} 15 \mathrm{C} 5+\mathrm{Na}\right]^{+}$and $\left[\mathrm{NO}_{2} \mathrm{~B} 15 \mathrm{C} 5+\right.$ $\mathrm{Na}]^{+}$are the only crown ether complexes obtained in the solution containing excess $\mathrm{Na}^{+}$cations. The peaks of the ions $\left[\mathrm{NH}_{2} \mathrm{~B} 15 \mathrm{C} 5+\mathrm{K}\right]^{+}$and $\left[\mathrm{NO}_{2} \mathrm{~B} 15 \mathrm{C} 5+\mathrm{K}\right]^{+}$ are also similar, and the latter has $88 \%$ relative intensity of the former; however, this result is slightly worse than that obtained for sodium complexes. The ESI mass 

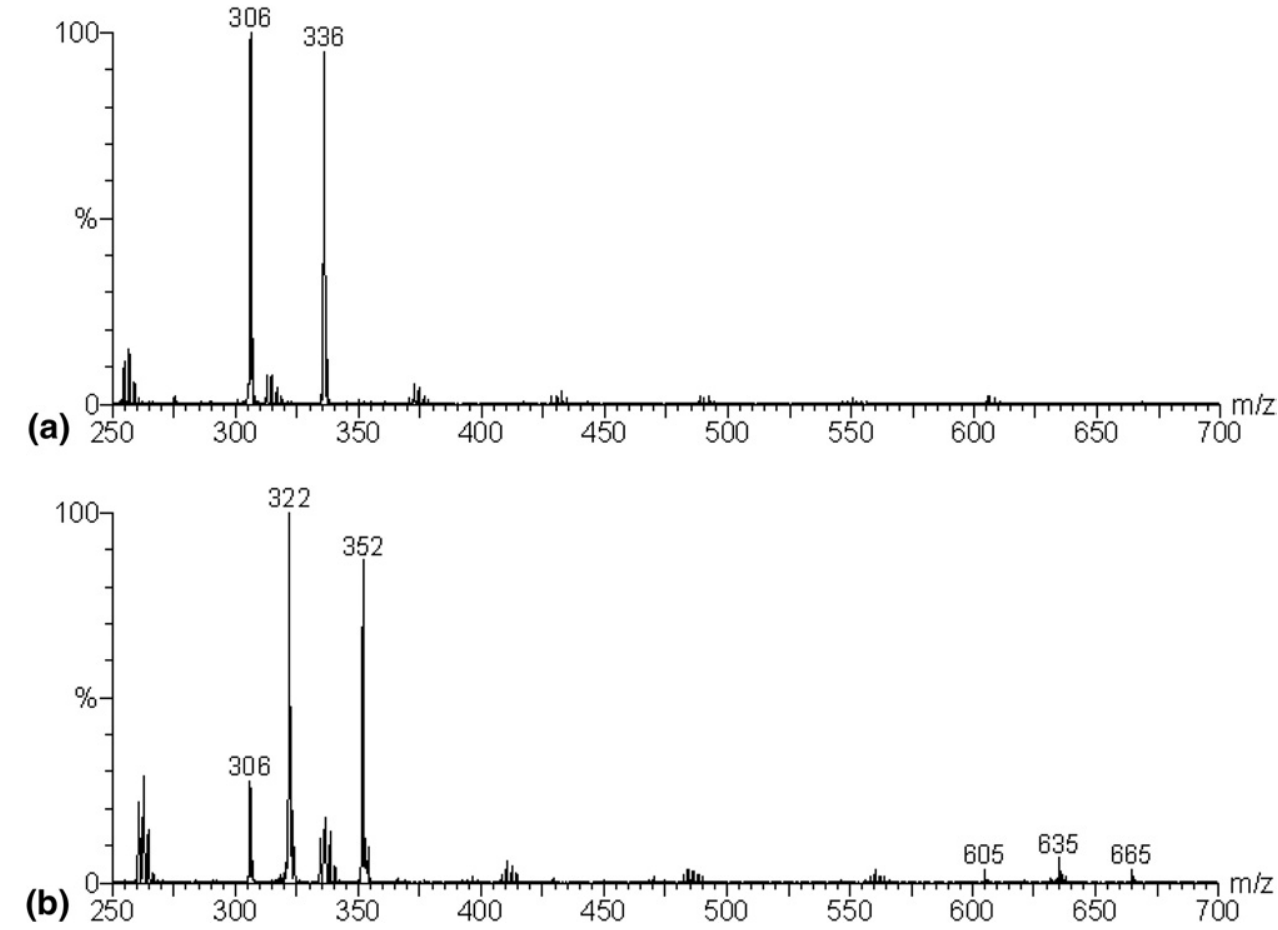

Figure 2. ESI mass spectra of methanol solutions containing (a) $\mathrm{NH}_{2} \mathrm{~B} 15 \mathrm{C} 5, \mathrm{NO}_{2} \mathrm{~B} 15 \mathrm{C} 5$, and an excess of (a) $\mathrm{Na}^{+}$cations $\left(\mathrm{NaCl}\right.$ was added), (b) $\mathrm{K}^{+}$cations ( $\mathrm{KCl}$ was added). $\left[\mathrm{NH}_{2} \mathrm{~B} 15 \mathrm{C} 5+\mathrm{Na}\right]^{+} \mathrm{m} / \mathrm{z} 306$, $\left[\mathrm{NO}_{2} \mathrm{~B} 15 \mathrm{C} 5+\mathrm{Na}\right]^{+} \mathrm{m} / z 336,\left[\mathrm{NH}_{2} \mathrm{~B} 15 \mathrm{C} 5+\mathrm{K}\right]^{+} \mathrm{m} / z$ 322, $\left[\mathrm{NO}_{2} \mathrm{~B} 15 \mathrm{C} 5+\mathrm{K}\right]^{+} \mathrm{m} / z 352,\left[\left(\mathrm{NH}_{2} \mathrm{~B} 15 \mathrm{C} 5\right)_{2}+\mathrm{K}\right]^{+}$ $m / z$ 605, $\left[\mathrm{NH}_{2} \mathrm{~B} 15 \mathrm{C} 5+\mathrm{NO}_{2} \mathrm{~B} 15 \mathrm{C} 5+\mathrm{K}\right]^{+} \mathrm{m} / z$ 635, $\left[\left(\mathrm{NO}_{2} \mathrm{~B} 15 \mathrm{C} 5\right)_{2}+\mathrm{K}\right]^{+} m / z$ 665. Clusters $\left[(\mathrm{NaCl})_{\mathrm{n}}+\mathrm{Na}\right]^{+}$ (a) and clusters $\left[(\mathrm{KCl})_{\mathrm{n}}+\mathrm{K}\right]^{+}\left(\right.$b) are clearly seen-cluster $\left[(\mathrm{KCl})_{4}+\mathrm{K}\right]^{+}$overlaps with ion $\left[\mathrm{NO}_{2} \mathrm{~B} 15 \mathrm{C} 5+\mathrm{Na}\right]^{+}$.

spectrum obtained for the solution containing crown ethers and an excess of $\mathrm{K}^{+}$cations indicates that not all crown ether molecules form 1:1 complexes with $\mathrm{K}^{+}$ cations. There are complexes with $\mathrm{Na}^{+}$cations and there are complexes with $\mathrm{K}^{+}$cations of 2:1 stoichiometry. The explanation is that the $\mathrm{K}^{+}$cation is too large to fit well into the crown ether cavities (in contrast to the $\mathrm{Na}^{+}$cation) and, therefore, other complexes are also formed. It can be assumed that if 1:1 complexes have similar ESI responses, the 2:1 complexes (formed by the same crown ethers) will have similar responses as well.

\section{The Effect of Solvent and Metal Cation Radius}

If the discussed $\pi$-stacking interactions exist in solution, a change in solvent should lead to visible changes in relative peak intensities. Acetonitrile is expected to decrease the $\pi$-stacking interactions in the complexes studied since this solvent can be a source of $\pi$-stacking interactions itself. Water, a solvent much more polar than methanol, is also expected to affect the $\pi$-stacking interactions. Figure 3 shows the ESI mass spectra, in the $\mathrm{m} / \mathrm{z}$ range of 2:1 complexes, obtained by using methanol/acetonitrile and methanol/water as solvents, both in 1:1 stoichiometry.

As clearly seen, in both cases the formation of the mixed-ligand complex is not favored in comparison to homo-ligand complexes, indicating that the $\pi$-stacking interactions observed in pure methanol have disap- peared. We have searched for a solvent in which the $\pi$-stacking interactions could be enhanced, in comparison to methanol, for example methanol/chloroform.

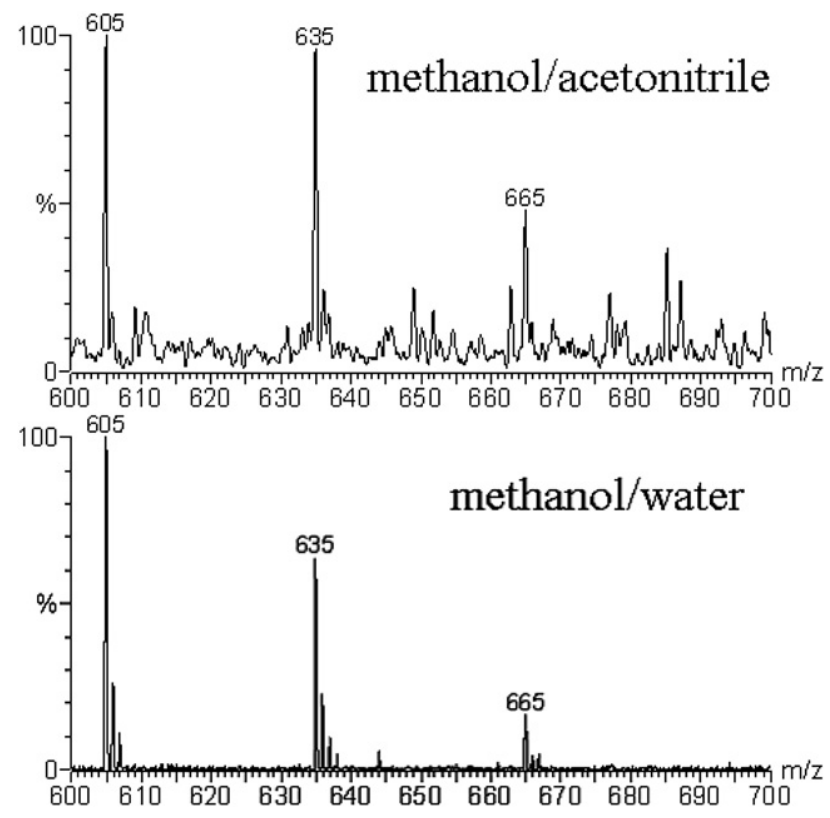

Figure 3. ESI mass spectra, in $\mathrm{m} / \mathrm{z}$ range of $2: 1$ complexes, obtained by using methanol/acetonitrile (1/1) and methanol/ water $(1 / 1)$ as solvents. In methanol/acetonitrile the complexes have low abundance because coordination of the alkali metal cation by acetonitrile disturbs formation of the complexes [20]. 


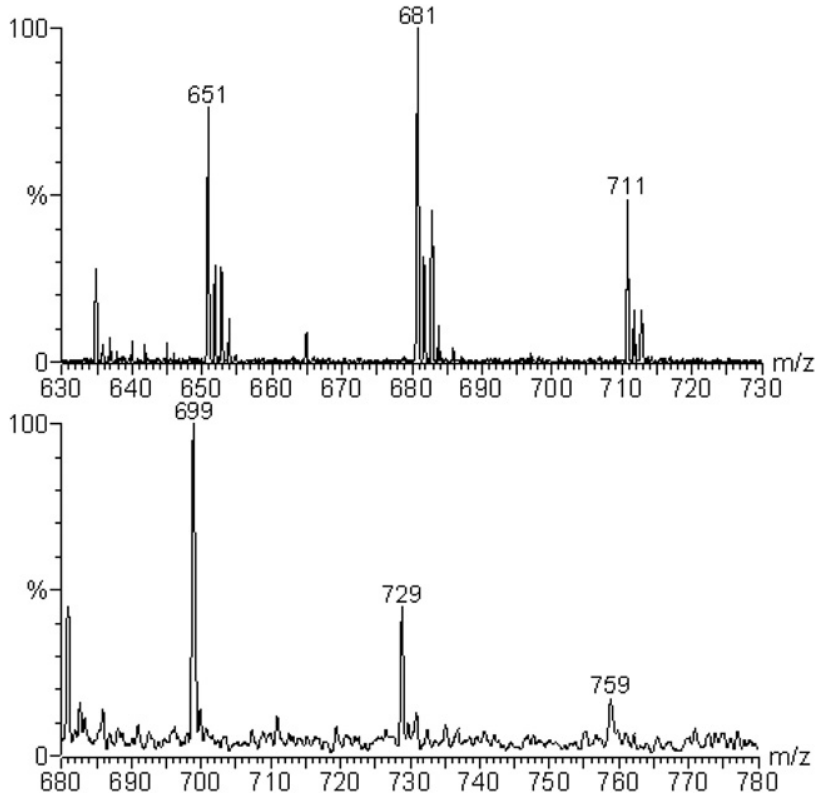

Figure 4. ESI mass spectra, in $\mathrm{m} / \mathrm{z}$ range of 2:1 complexes, obtained after adding $\mathrm{RbClO}_{4}$ (left) and $\mathrm{CsClO}_{4}$ (right) to the analyzed methanol solution; $\left[\left(\mathrm{NH}_{2} \mathrm{~B} 15 \mathrm{C} 5\right)_{2}+\mathrm{Rb}\right]^{+} \mathrm{m} / \mathrm{z} 651$, $\left[\left(\mathrm{NO}_{2} \mathrm{~B} 15 \mathrm{C} 5\right)_{2}+\mathrm{Rb}\right]^{+} \mathrm{m} / z \mathrm{z} 11,\left[\mathrm{NH}_{2} \mathrm{~B} 15 \mathrm{C} 5+\mathrm{NO}_{2} \mathrm{~B} 15 \mathrm{C} 5+\mathrm{Rb}\right]^{+}$ $\mathrm{m} / \mathrm{z}$ 681, $\left[\left(\mathrm{NH}_{2} \mathrm{~B} 15 \mathrm{C} 5\right)_{2}+\mathrm{Cs}\right]^{+} \mathrm{m} / z$ 699, $\left[\left(\mathrm{NO}_{2} \mathrm{~B} 15 \mathrm{C} 5\right)_{2}+\mathrm{Cs}\right]^{+} \mathrm{m} / \mathrm{z}$ $759,\left[\mathrm{NH}_{2} \mathrm{~B} 15 \mathrm{C} 5+\mathrm{NO}_{2} \mathrm{~B} 15 \mathrm{C} 5+\mathrm{Cs}\right]^{+} \mathrm{m} / \mathrm{z} 729$

However, a significant increase in the abundance of the mixed-ligand complex relative to the homo-ligand complexes was never observed.

As described in detail by Sherman et al. [7], the size of the metal cation is of crucial importance for the contribution of $\pi$-stacking interactions in the sandwich complexes. As shown in Figure 4, the mixed-ligand complexes are more abundant than the homo-ligand complexes for rubidium but not for cesium.

Because of the large radius of the $\mathrm{Cs}^{+}$cation, the interaction between aromatic rings is not possible. This finding is additional confirmation that in the $\left[\mathrm{NH}_{2} \mathrm{~B} 15 \mathrm{C} 5+\mathrm{NO}_{2} \mathrm{~B} 15 \mathrm{C} 5+\mathrm{K}\right]^{+}$ions (and also in $\left[\mathrm{NH}_{2} \mathrm{~B} 15 \mathrm{C} 5+\mathrm{NO}_{2} \mathrm{~B} 15 \mathrm{C} 5+\mathrm{Rb}\right]^{+}$ions), $\pi$-stacking interactions are important.

\section{Appendix A Supplementary Material}

Supplementary material associated with this article may be found in the online version at doi:10.1016/ j.jasms.2009.12.018.

\section{References}

1. Gokel, G. W.; Leevy, W. M.; Weber, M. E. Crown Ethers: Sensors for Ions and Molecular Scaffolds for Materials and Biological Models. Chem. Rev. 2004, 104, 2723-2750.

2. Leize, E.; Anne Jaffrezic, A.; Van Dorsselaer, A. Correlation Between Solvation Energies and Electrospray Mass Spectrometric Response Factors. Study by Electrospray Mass Spectrometry of Supramolecular Complexes in Thermodynamic Equilibrium in Solution. J. Mass Spectrom. 1996, 31, 537-544

3. Shen, N.; Pope, R. M.; Dearden, D. V. Fundamental Factors Controlling the Exchange of Multidentate Ligands: Displacement of 12-Crown-4 and Triglyme from Complexes with Divalent Alkaline Earth Cations. Int. J. Mass Spectrom. 2000, 195/196, 639-652.

4. Nicoll, J. B.; Dearden, D. V. Reactions of Multidentate Ligands with Ligated Alkali Cation complexes: Self-Exchange and "Sandwich" Complex Formation Kinetics of Gas Phase Crown Ether-Alkali Cation Complexes. Int. J. Mass Spectrom. 2001, 204, 171-183.

5. Chu, I.-H.; Zhang, H.; Dearden, D. V. Macrocyclic Chemistry in the Gas Phase: Intrinsic Cation Affinities and Complexation Rates for Alkali Metal Cation Complexes of Crown Ethers and Glymes. J. Am. Chem. Soc. 1993, 115, 5736-5744.

6. Oshima, T.; Matsuda, F.; Fukushima, K.; Tamura, H.; Matsubayashi, G. Arakawa, R. Selective Cation Binding of Crown Ether Acetals in Electrospray Ionization Mass Spectrometry. J. Chem. Soc. Perkin Trans. 1998, 2, 145-148.

7. Sherman, C. L.; Brodbelt, J. S.; Marchand, A. P.; Poola, B. Electrospray Ionization Mass Spectrometric Detection of Self-Assembly of a Crown Ether Complex Directed by $\pi$-Stacking Interactions. J. Am. Soc. Mass Spectrom. 2005, 16, 1162-1171.

8. Yamaguchi, N.; Gibson, H. W. Noncovalent Chemical Modification of Crown Ether Side-chain Polymethacrylates with a Secondary Ammonium Salt: A Family of New Polypseudorotaxanes. Macromol. Chem. Phys. 2000, 201, 815-824.

9. Bryant, W. S.; Guzei, I. A.; Rheingold, A. L.; Merola, J. S.; Gibson H. W. A Study of the Complexation of Bis ( $m$-Phenylene) Crown Ethers and Secondary Ammonium Ions. J. Org. Chem. 1998, 63, 7634-7639.

10. Meyer, E. A.; Castellano, R. K.; Diederich, F. Interactions with Aromatic Rings in Chemical and Biological Recognition. Angew. Chem. Int. Ed. 2003, 42, 1210-1250.

11. Ma, J. C.; Dougherty, D. A. The Cation- $\pi$ Interaction. Chem. Rev. 1997, 97, 1303-1324.

12. Gallivan, J. P.; Dougherty, D. A. Cation- $\pi$ interactions in structura biology. Proc. Natl. Acad. Sci. U.S.A. 1999, 96, 9459-9464.

13. Maleknia, S.; Brodbelt, J. Cavity-Size-Dependent Dissociation of Crown Ether/Ammonium Ion Complexes in the Gas Phase. J. Am. Chem. Soc. 1993, 115, 2837-2843.

14. Colton, R.; Mitchell, S.; Traeger, J. C. Interactions of Some Crown Ethers, Cyclam, and Its Tetrathia Analogue with Alkali, Alkali Earth, and Other Metal Ions: An Electrospray Mass Spectrometric Study. Inorg. Chim. Acta 1995, 231, 87-93.

15. Emsley, J. The Elements. Oxford Chemistry Guides 2nd ed.; Clarendon Press: Oxford, 1991; p. 156, 186.

16. Frański, M.; Przybysz, I.; Borkowska, M.; Kozik, T. Cationization Versus Surface Activity-The Effect on Electrospray Ionization. Eur. J. Mass Spectrom. 2006, 12, 15-18

17. Frański, R.; Gierczyk B.; Schroeder, G. Anion- $\pi$ Interactions-Interaction Between Benzo-Crown Ether Metal Cation Complexes and Counter Ion. J. Am. Soc. Mass. Spectrom. 2009, 20, 257-262.

18. Leize, E.; Jaffrezic A. A.; Van Dorsselaer, A. Correlation Between Solvation Energies and Electrospray Mass Spectrometric Response Factors. Study by Electrospray Mass Spectrometry of Supramolecular Complexes in Thermodynamic Equilibrium in Solution. J. Mass Spectrom. 1996, 31, 537-544.

19. Reyzer, M. L.; Brodbelt, J. S.; Marchand, A. P.; Chen, Z.; Huang Z.; Namboothiri, I. N. N. Determination of Alkali Metal Binding Selectivities of Caged Crown Ligands by Electrospray Ionization Quadrupole Ion Trap Mass Spectrometry. Int. J. Mass Spectrom. 2001, 204, 133-142.

20. Frański, R.; Schroeder, G.; Gierczyk, B.; Niedziałkowski, P.; Ossowski, T. Formation of Stoichiometric Complexes between Dibenzo-30Crown-10 and Guanidinium Moiety Containing Compounds. Int. J. Mass Spectrom. 2007, 266, 180-184. 